\title{
Parameters of reproductive activity in females of Harmonia axyridis (Coleoptera: Coccinellidae)
}

\author{
George J. Stathas, Panagiotis A. Eliopoulos, Dimitrios C. KONTODiMAS and John GIANNOPAPAS \\ Laboratory of Biological Control, Benaki Phytopathological Institute 8 S. Delta str., GR 14561 Kifissia, Athens, Greece, Fax: \\ +30-1-8077506; e-mail: georgestathas@hotmail.com
}

Key words. Coccinellidae, Harmonia axyridis, reproductive activity, fecundity, mating, number of ovarioles, batch size, Aphis fabae, temperature

\begin{abstract}
The effects of temperatures of $15,20,25$ and $30^{\circ} \mathrm{C}$ on the duration of premating and preoviposition periods of Harmonia axyridis reared on the aphid Aphis fabae, were compared in the laboratory. The course of oviposition was monitored at $25^{\circ} \mathrm{C}$ in females reared on Aphis fabae and the peak of egg laying was recorded at the age of 15 to 45 days. The size of egg groups (batch size), as well as daily and total fecundity was recorded. Half of the total number of eggs was laid in batches of 10-30 eggs. The mean daily and total fecundity reached a maximum of 42 and 1,641.6 eggs, respectively. Adult females oviposited for almost their entire life.
\end{abstract}

\section{INTRODUCTION}

Harmonia axyridis Pallas (Coleoptera: Coccinellidae) is an important natural enemy of aphids, coccids and other homopterous insects (Tedders \& Schaefer, 1994; McClure, 1987). It was introduced to the U.S.A. (Tedders \& Schaefer, 1994) and Europe (Schanderl et al., 1985; Katsoyannos et al., 1997) to control aphids, where it established successfully.

Many studies have been published on $H$. axyridis, particularly after its establishment in USA and Canada (Dreistad et al., 1995; Coderre et al., 1995; Colunga-Garcia \& Cage, 1998). The success of the French team in producing flightless strains has increased the potential of $H$. axyridis in biological control and integrated pest management (Ferran et al., 1998). The rearing of this coccinellid on eggs of Ephestia kuehniella Zell. is easy, but modifies its type of foraging: the larvae lose the ability to change from extensive searching to intensive searching (Ferran et al., 1997). We have thus decided to use aphids as prey, as $H$. axyridis should be used to control Aphis fabae Scop.

Lamana \& Miller (1998) used Acyrthosiphon pisum (Harris) as prey and compared developmental rate and mortality at six temperatures. While the rate of development increases until $34^{\circ} \mathrm{C}$, mortality rate becomes too high at temperatures $>26^{\circ} \mathrm{C}$. We have therefore chosen $25^{\circ} \mathrm{C}$ for our experiments. Our main aim was to monitor the course of oviposition during the life of females when they are fed with $A$. fabae, and also to record the effect of temperature on the young females, as similar information has not been previously published.

\section{MATERIALS AND METHODS}

Harmonia axyridis has been imported from France and reared in the insectary of the Benaki Phytopathological Institute since 1993 (Katsoyannos et al., 1997). The experiments were conducted by feeding $H$. axyridis on Aphis fabae Scopoli reared on seedlings of Vicia faba L. (Leguminosae). Duration of preoviposition period was studied at $15 \pm 1^{\circ}, 20 \pm 1^{\circ}, 25 \pm 1^{\circ}$ and $30 \pm$ $1^{\circ} \mathrm{C}$. Fecundity was measured at $25 \pm 1^{\circ} \mathrm{C}$. In all cases, relative humidity was $65 \pm 1 \%$ and photoperiod $16 \mathrm{~h}$ light per day. Malefemale pairs were reared in cylindrical plastic cages $(16 \mathrm{~cm}$ in height and $13 \mathrm{~cm}$ in diameter). The adults were sexed using the shape of the 5th abdominal sternite. Prey was supplied and observations made once a day.
For the premating period of females, 150 females and mature males of 10-30 days old were reared in male-female pairs, for 10 days after the emergence of females, at each temperature. Fifteen females were dissected daily from the day 1 to 10 and their spermatheca was observed under microscope for the presence of sperm.

The influence of temperature on the preoviposition period was studied for 30 females (in male-female pairs of the same age), in every temperature, from emergence. The thermal summation method was used to estimate the thermal constant $(\mathrm{K})$ for the preoviposition period. The data for the duration of preoviposition period in different temperatures were tested for significance using analysis of variance (ANOVA) and the means were separated by Student's t-test (Landi, 1977).

Fecundity was determined for 30 females reared in malefemale pairs of the same age throughout their lifetime. In case the male died, another male replaced it. Beetles were supplied with abundance of $A$. fabae aphids daily, in order to avoid egg cannibalism.

\section{RESULTS}

The start of mating and the time when all females have mated under different constant temperatures is shown in Fig. 1. Females reproduced later by lower rearing temperature. At $30^{\circ} \mathrm{C}$, first mating occurred on the 2 nd day and at $25^{\circ} \mathrm{C}$ on the $3 \mathrm{rd}$, whereas all individuals mated after 2 days (on the 4th and 5 th day, respectively). At $20^{\circ} \mathrm{C}$ the first matings were observed on the 4th day and at $15^{\circ} \mathrm{C}$ on the 5 th, whereas all individuals mated by the 7 th and 10 th day, respectively.

The mean duration of preoviposition period at 15, 20, 25 and $30^{\circ} \mathrm{C}$, was calculated $21 \pm 3.05,10.8 \pm 1.44,7.2 \pm 1.12$ and 4.6 \pm 0.73 (mean $\pm \mathrm{SD}$ ) days, respectively. Means for $15^{\circ} \mathrm{C}$ and $20^{\circ} \mathrm{C}, 20^{\circ} \mathrm{C}$ and $25^{\circ} \mathrm{C}, 25^{\circ} \mathrm{C}$ and $30^{\circ} \mathrm{C}$ were significantly different $[(\mathrm{t}=16.3, \mathrm{df}=56, P<0.01),(\mathrm{t}=10.6, \mathrm{df}=56, P<0.01)$ and $(\mathrm{t}=10.5, \mathrm{df}=56, P<0.01)$ respectively]. The regression line is $\mathrm{y}=0.0113 \mathrm{x}-0.1276, \mathrm{R}^{2}=0.9905$ (where: $\mathrm{y}=$ developmental rate, $x=$ temperature, $R^{2}=$ coefficient of determination). The calculated thermal constant $(\mathrm{K})$ was 90.1 degree-days and developmental threshold (t) $11.3^{\circ} \mathrm{C}$. 


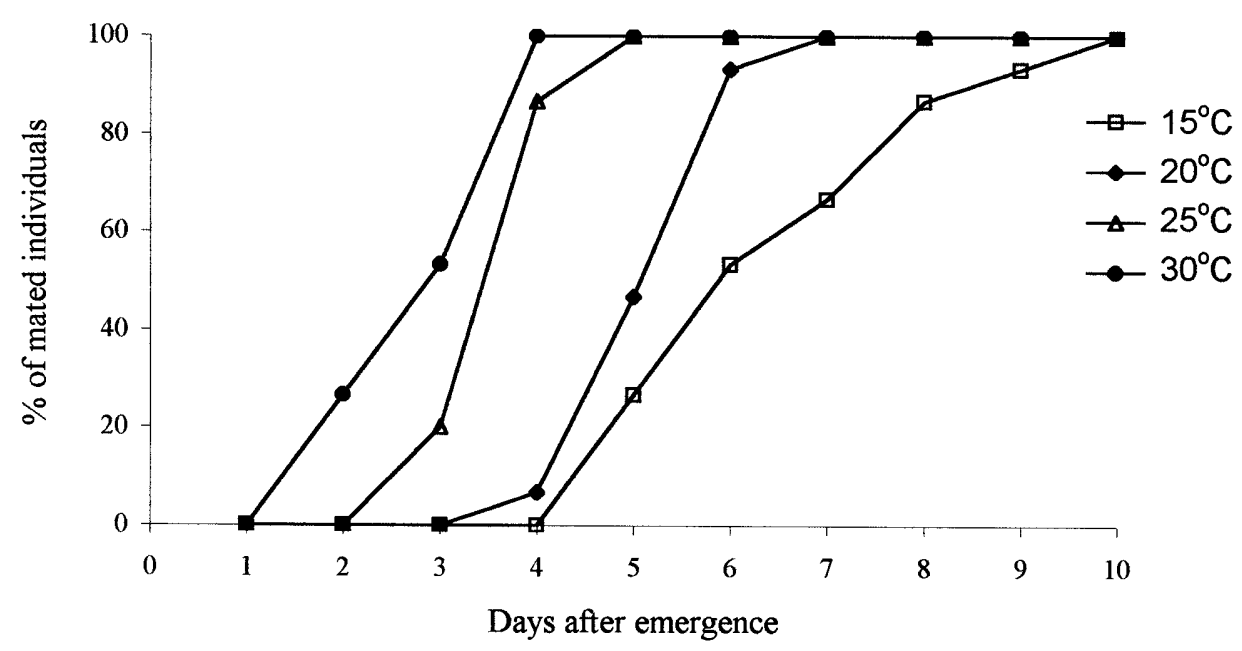

Fig. 1. Effect of temperature on the premating period of $H$. axyridis $(\mathrm{N}=15)$.

More than a half of the total number of eggs was laid in batches of 11-20 (26.5\%) and 21-30 (25.7\%) eggs (Fig. 2). Mean number of eggs per batch was $29.5 \pm 12.10($ mean \pm SD) eggs.

The average daily fecundity (Fig. 3), increased during the 1st and 2 nd decade, reached the highest values during the $3 \mathrm{rd}$ and 4 th decade and decreased in the 5 th through 8 th decades. The maximum daily fecundity of the females fluctuated between 59 and 78 eggs and was recorded at days 20-46 after emergence. Most females continued to oviposit throughout their entire life, which lasted $60.7 \pm 14.85$ days. Six females ceased oviposition $5.3 \pm 2.8$ days before death.

The total fecundity of $H$. axyridis females ranged from 703 to 2.263 eggs (mean \pm S.D.: $1,641.6 \pm 420.95$ ). Ninety per cent of the examined females laid more than $1,000,70 \%$ more than 1,500 and $16.7 \%$ more than 2,000 eggs.

\section{DISCUSSION}

Temperature influences the premating period of $H$. axyridis (Fig.1). This is due to the fact that female maturation is probably related to a process of production of sexual attractant, which is faster in higher temperature. Obata (1987) suggested that at $20-25^{\circ} \mathrm{C}$ and $16 \mathrm{~L}: 8 \mathrm{D}$, copulation occurred in $3-4$ days after emergence. In spite of different prey (Aphis citricola van der Goot) this was not significantly different from our data.

In the present study, the preoviposition period of $H$. axyridis lasted 7.2 days at $25^{\circ} \mathrm{C}$ and 4.6 days at $30^{\circ} \mathrm{C}$. The duration of preoviposition period was similar $\left(8-10\right.$ days at $\left.25^{\circ} \mathrm{C}\right)$ when $H$. axyridis was reared on eggs of moth Ephestia kuehniella (Brun, 1993). On artificial diet the preoviposition period was much longer : 7 days at $30^{\circ} \mathrm{C}$ (Hong \& Park, 1996). These differences can be attributed to different foods (Hodek \& Honěk, 1996).

The majority of eggs (more than $50 \%$ ), was laid in batches of 11-20 and 21-30 eggs (Fig. 2), with an average of 29.5 eggs per batch. Similar size of egg-clutches of $H$. axyridis was reported from the field by Takahashi (1987) : $23.0 \pm 7.8$ eggs per batch on alfalfa and $31.4 \pm 15.1$ on weeds. The number of eggs in a batch may largely vary due to trophic conditions and the substrate, but the modal size is typical for different species of coccinellids (Hodek \& Honěk, 1996).

The mean total fecundity of $H$. axyridis recorded in the present study $(1,641.6 \pm 420.95$ eggs per female), differs from pre-

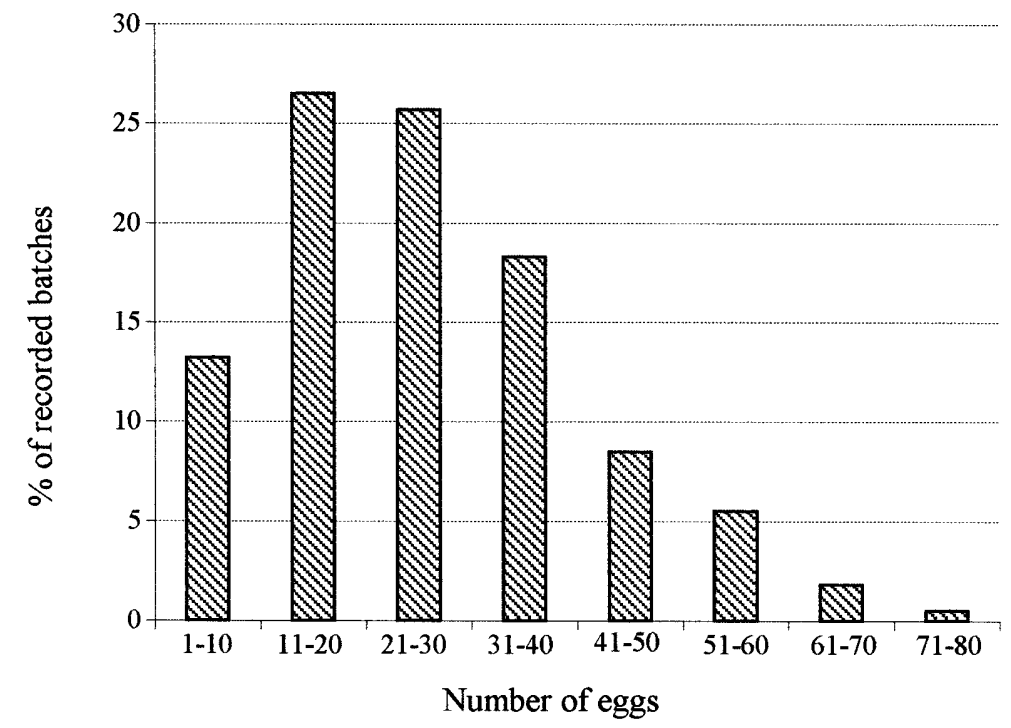

Fig. 2. Distribution of egg batch size $(\mathrm{N}=49,307 \mathrm{eggs})$. 


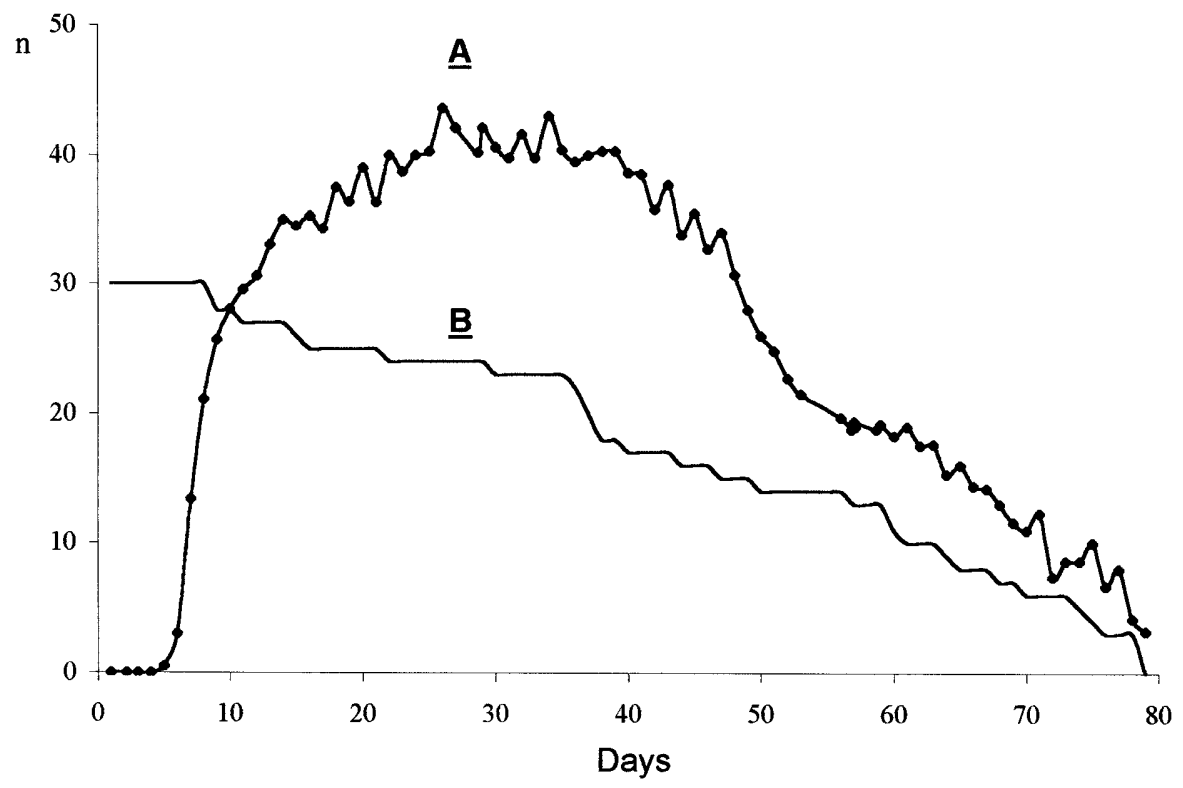

Fig. 3. Fecundity and survival of $H$. axyridis $(\mathrm{N}=30)$ : Average number of eggs laid $(\underline{\mathrm{A}})$ and survival $(\underline{\mathrm{B}})$ of 30 females.

vious studies. Hong \& Park (1996) observed that H. axyridis laid only $163.9 \pm 144$ eggs per female, when the coccinellids were reared on artificial diet. He et al. (1994) reported that $H$. axyridis laid 751 eggs per female, under $14.5-18^{\circ} \mathrm{C}$, when Aphis gossypii was used as prey. A similar value $(718.7 \pm 93.6$ eggs per female) was recorded by McClure (1987), who reared $H$. axyridis on the aphid Acyrthosiphon pisum (Harris) at $27^{\circ} \mathrm{C}$. Hukusima \& Kamei (in Hodek, 1973), recorded 2,310 and 778 eggs per female when fed on the aphid Myzus persicae (Sulzer) at $25^{\circ} \mathrm{C}$ and $30^{\circ} \mathrm{C}$, respectively, and 3,819 and 945 eggs per female when fed on Amphorophora oleracea (van der Goot) at $25^{\circ} \mathrm{C}$ and $30^{\circ} \mathrm{C}$, respectively. The above-mentioned differences in the fecundity of $H$. axyridis can be attributed to different prey and temperature.

\section{REFERENCES}

BRUN J. 1993: Biological Control in the ozchard: Harmonia axyridis (Pallas), a new exotic predator for control of aphids. Infos (Paris) 94: 41-42

Coderre D., Lucas E. \& Gagne I. 1995: The occurrence of Harmonia axyridis (Pallas) (Coleoptera Coccinellidae) in Canada. Can. Entomol. 127: 609-611.

Colunga-Garcia M. \& Gage S.H. 1998: Arrival, establishment, and habitat use of the multicolored Asian lady beetle (Coleoptera: Coccinellidae) in a Michigan landscape. Environ. Entomol. 27: 1574-1580.

Dreistadt S.H., Hagen K.S. \& Bezark L.G. 1995: Harmonia axyridis (Pallas) (Coleoptera: Coccinellidae), first western United States record for this Asiatic lady beetle. Pan Pac. Entomol. 71: 135-136.

Ferran A., Gambier J., Parent S., Legendre K., Tourniere R. \& Givge L. 1997. The effect of rearing the ladybird Harmonia axyridis on Ephestia kuehniella eggs on the response of its larvae to aphid tracks. J. Insect Behav. 10: 129-144.

Ferran A., Guige L., Tourniaire R., Gambier J. \& Fournier D. 1998: An artificial no-flying mutation to improve the efficiency of the ladybird Harmonia axyridis in biological control of aphids. BioControl 43: 53-64.

He J.L., MA E.P., Shen Y.C., Chen W.L. \& Sun X.Q. 1994: Observations of the biological characteristics of Harmonia axyridis (Pallas) (Coleoptera: Coccinellidae). J. Shanghai Agric. Coll. 12: 119-124.

HodeK I. 1973: Biology of Coccinellidae. Czechoslovak Academy of Sciences, Prague, Czechoslovakia, 260 pp.

Hodek I. \& HonĚK A. 1996: Ecology of Coccinellidae. Kluwer Academic Publishers, Dordrecht, 464 pp.

HONG O.K. \& PARK Y.C. 1996: Laboratory rearing of the aphidophagous ladybeetle, Harmonia axyridis; yolk protein production and fecundity of the summer adult female. Korean $J$. Appl. Entomol. 35: 146-152.

Katsoyannos P., Kontodimas D.C., Stathas G.J. \& Tsartsalis C.T. 1997: Establishment of Harmonia axyridis on citrus and some data on its phenology in Greece. Phytoparasitica 25: 183-191.

Lamana M.L. \& Miller J.C. 1998: Temperature-dependent development in an Oregon population of Harmonia axyridis (Coleoptera: Coccinellidae). Environ. Entomol. 27: 1001-1005.

LANDI R. 1977: Lezioni di Metodologia e Tecnica Sperimentale. Cedam, Padova, Italy, 234 pp.

MCClure M.S. 1987: Potential of the Asian predator Harmonia axyridis Pallas (Coleoptera: Coccinellidae), to control Matsucoccus resinosae Bean and Godwin (Homoptera: Margarodidae) in the United States. Environ. Entomol. 16: 224-230.

Овата S. 1987: Mating behavior and sperm transfer in the ladybird beetle, Harmonia axyridis Pallas (Coleoptera: Coccinellidae). Appl. Entomol. Zool. 22: 434-442.

Schanderl H., Ferran A. \& Larroque M.M. 1985: Les besoins trophiques et thermiques des larves de la coccinelle Harmonia axyridis Pallas. Agronomie 5: 417-421.

TAKAHASH K. 1987: Differences in oviposition initiation and sites of lady beetles, Coccinella septempunctata bruckii Mulsant and Harmonia axyridis (Pallas) (Coleoptera: Coccinellidae) in the field. Jpn. J. Appl. Entomol. Zool. 31: 253-254.

Tedders W.L. \& Schaefer P.W. 1994: Release and establishment of Harmonia axyridis (Coleoptera: Coccinellidae) in the southeastern United States. Entomol. News 105: 228-243.

Received January 3, 2001; revised June 25, 2001; accepted September 14, 2001 